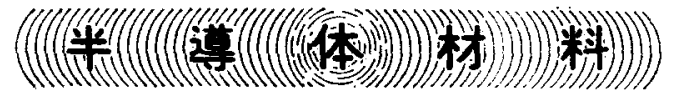

(14)

\title{
III-V 化合物結晶の作り方とその性質
}

\section{1 緒言

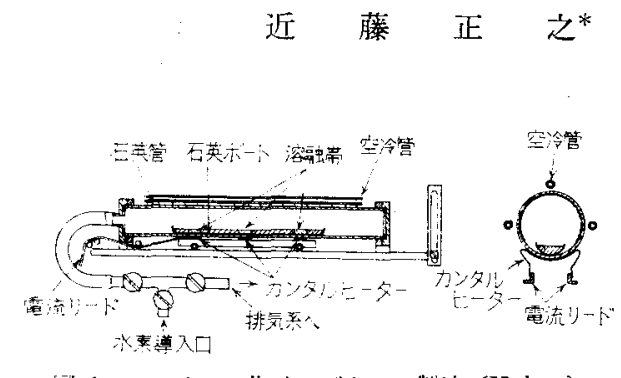 \\ 网 1 アンチモン化インジウムの撆法 (Hulme)}

1952 年に Welker によってつくられた III $-\mathrm{V}$ 族化 合物半導体もその後数多くの研究者によって, 製法なら びに利用面の研究がなされてきた。最近になっては七化 ガリウムの半導体レーザー, マイクロ波の発振現象, ま たリン化ガリウムからの间視光線の放射など従来の半導 体のシリコンやゲルマニウムと異なった興味ある現象の 発見のために，その将来に対す尚期待もかなり大きくな ってきた。

しかし III $-V$ 族化合物半導体の発見以来 10 年以上 経過しているのに対し，その実用化があまり活発でない のはゲルマニウムのような単原子組成の半導体上比べる 上その成分元素の蒸気压の高いものがあるために結晶製 作技術が複雑になり，ひいては化学量論組成の結唱をつ くることがむずかしくなるためである。そこでこれらの 製法を概観すると蒝気压の高い元素を成分に含んでいる ものはその蒸気圧の制御に複雑な技術が要求されてい る・をた一方ではこ礼らの困難をさけるために気相反応 で結晶をつくる気相成長法，ならびに溶融金属の中に溶 解させてこれに温度差を字えて，低温部に析出させる T.S.M. 法 (Travelling Solvent Method) などが考案 されている。

\section{2 製法}

\section{1 アンチモン化インジゥム（InSb)}

これは III $-\mathrm{V}$ 族化合物半導の中でも最も融点が低人 此較的作りやすい半導体である。しかし亜鉛, カドミウ ムなどの不純物は蒸気圧が高いために帯溶融法による精 製は困難であるために高純度のものを作るには特別な注 意が必要である。これは図1に示すように $99.999 \% の$ ガリウムと帯溶融法で精製したアンチモンを化学量論比 にひよう量して石英ボートに入れる。そしてこれを石英 管の中にそら入して排気した後石英ボート全体を加熱し 揮発性の不純物を蒸発させる。この際に，外側の石英管 の周囲にある3本の細、管に空気を圧送して石英管を椧 却寸る、したがって蒸発した不純物は石英管の内面に凝

\footnotetext{
，東京芝浦電気株式会社中央研究所（神奈川県川䗁市小向東茫町）
} 縮する、不純物を蒸発させた後，ヒータ一の電力を調整 し石英ボートの中の一部分を溶融させ, 带溶融法によ一

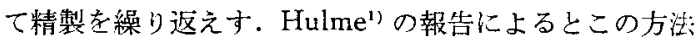
で $5 \mathrm{hr}$ 不純物の加熱蒸発を行なった後, 20 回帯溶融法 によって精製を行なった結晶では不純物莀度は $10^{14}$ $\mathrm{cm}^{-3}$ の $n$ 型であり，電子の易動度は $77^{\circ} \mathrm{K}$ で 500,000 $\mathrm{cm}^{2} / \mathrm{Vsec}$ 以上のものがえられた。 またこの場合に精製 のときに流す水素ガス中に不純物として酸素, 水蒸気な どが混入していると溶融体の表面は酸化する。このよう な状態では結晶が石英ボートに粘着し結晶核発生の原因 となり単結晶成長の妨げとなる．また引き上げ法の場合 にも酸化物が双晶などの発生の原因となる。酸化物の除 去には純度の高、水素気流中で 800 900 $\mathrm{C}$ に加熱する と比較的容易に還元され金属光沢の清浄な溶融体の表面门 にすることができる．したがって酸化物を除くことはア ンチモン化インヂウムに限らず一般に単結晶成長の際に は重要なことでありいろいるな考案がなされている。こ れらについては次の項でふれることとする。

\section{2 アンチモン化アルミニウム (AISb)}

Allred ら ${ }^{2)}$ は図2に示すような装置を用いてアンチモ ン化アルミニウムの合成を行ならと同時に引き上げ法に 上って単結晶の製作を行なった。これは水冷のできる真 空容器の中に加熱用ヒーター, 溶融用のルツボ,などを おさめる，真空容器には真空にするためと，ガスを流入 寸るためのバルブがついている，純度の高、結晶をつく るためには素材のアルミニウム、アンチモンはともに带 溶融法を20 回繰り返えして精製された後, 化学エッチ を行ない，純水でよく水洗したものを用いる.アルミニ ウムはアルミナのルッポの中に入れ，一方アンチモンは 容器の中のアルミナのチップに固定しておく．このよう に素材を分離して置いたまま装置をまず非気し，その後 
乾燥したヘリウムガスを導入する。これを数回繰り返え し装置の中をへリウムガスで洗浄する. 最後に装置の内 部を真空度 $10^{-3} \mathrm{mmHg}$ 以下に排気し，アルミニウムを $1000^{\circ} \mathrm{C}$ に長時間加熱する.この間にアルミニウムに混 入しているマグネシウムなどの揮発性不純物は蒸発す る。またこの処理の間にアルミニウムの表面にある酸化 物は 3〜4 時間で消失しはじめる.つぎにアルミナのチ ップに固定してお゙いたアンチモンを外部よりの操作でル ツボの中の溶融したアルミニウムの中に入れて反応させ 万. 反応が終わったならば容器内に 0.7 気压の乾燥へリ ウムガスを導入し, 溶融体の温度を溶融点付近の温度に 制御し引き上げ法によって単結晶を製作する。この寒騒 では引き上げ速度 $7.5 \mathrm{~cm} / \mathrm{hr}$ 以上では単結晶の製作には 戌功しなかった。

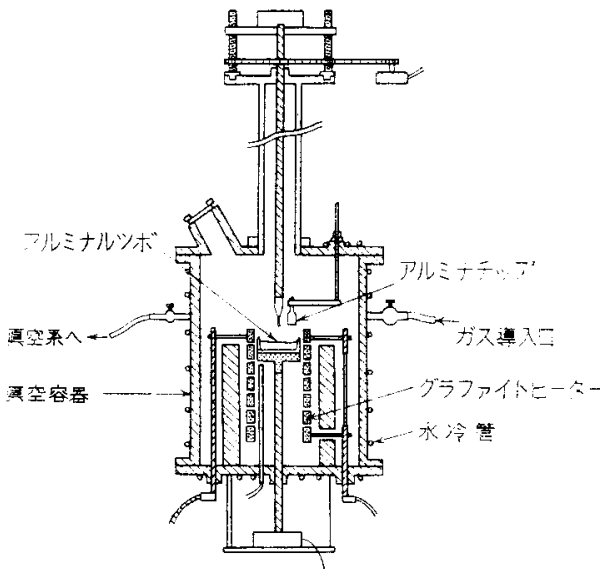

図 2 アソチモン化インジウムの引き上げ法 (Allred)

またこの装置では溶融体表面に酸化物が発生した場合 には，アルミナのチップを下してその表面に接触させ る。そのとき表面のみが急速に固化するのでチップを引 き上げると固化した表面がチップによって引き上げられ 表面の酸化物をルツボの外に取り除くことができる．こ のようにしてつくった純度の高い結晶は $p$ であり不純 物濃度は $9.4 \times 10^{16} \mathrm{~cm}^{-3}$ であったと報告されている。

\section{3 アンチモン化ガリウム（GaSb)}

アンチモン化ガリウムは融点も低くアンチモン化イン ジウムとともにつくりやすい化合物半遒体である。しか しアンチモン化インジウムよりは酸化しやすく酸化物の 涻去に注意を払はなければならない.Edwardは $99.99 \%$ のガリウムと $99.999 \%$ のアンチモンをグラファイトの ボートの中に入れ，水素统流中で反応させ，帯溶融法に より精製したものを，引き上げ法で単結唱にした。これ は $p$ 型で不純物濃度が $7.5 \times 10^{16} \mathrm{~cm}^{-3}$ であったと報告 されている゙๋.アンチモン化ガリウムはいくら精製を繰 り返えしても $p$ 型を示すことから常にガりウムが過剩 になっているもの上考えられる，現在のところ最も純度
の高い結晶は $2 \times 10^{16} \mathrm{~cm}^{-3}$ であり, 正孔の易動度は $77^{\circ} \mathrm{K}$ で $2470 \mathrm{~cm}^{2} / \mathrm{Vsec}$ である。

また Allred ら゙) は図 3 に示すように酸化物除 去法考考案している。こ れは下のルツボにアンチ モン化ガリウムの溶融体 を入れ，その表面が酸化 物で污染したときには底 に穴をけたルツボを降 し溶融体の中に沈める。 このとき底の穴より清浄 な溶融体が流れ込み，酸 化物は2つのルツボの間

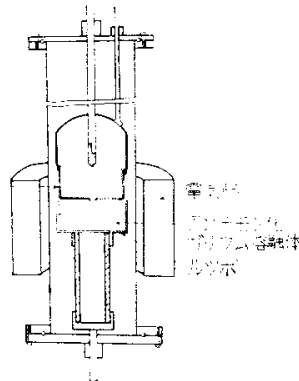

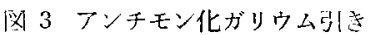
上げ装置 (Allred)
に集められ清浄な表面がえられる。これより引き上げ法 によって単結晶をつくることができる。

以上の 3 種類の化合物半導体は, 融点も低く,比較的蒸 気压も低く，そのために精製，製造技術も容易である。

\section{4 ヒ化ガリウム（GaAs）}

ヒ化ガリウムを含めてこれから後にのべる化合物半遒 体は、その成分の一つに蒸気圧の高い元素を含んでいる ために化学量論的組成の溶融体をつくる際には気相をも 含めた平衡状態を考えなければならない、ヒ化ガリウム については Boomgaard ら゙の実験により表 1 に示すよ らな固相一液相一気相の平衡状態が報告されている。 表 $1 \mathrm{Ga}-\mathrm{As}$ 系の As の蒸気左-温度-As の含有量の関係

\begin{tabular}{c|c|c|c}
\hline $\begin{array}{c}\text { 温 } \\
\left({ }^{\circ} \mathrm{C}\right)\end{array}$ & $\begin{array}{c}\text { 匕素の蒸気压 } \\
\text { (atm) }\end{array}$ & $\begin{array}{c}\text { 化合物の融点 } \\
\left({ }^{\circ} \mathrm{C}\right)\end{array}$ & $\begin{array}{c}\text { 溶融体中の七素の含有莗 } \\
\text { (atom\%) }\end{array}$ \\
\hline 386 & $6.2 \times 10^{-3}$ & $781 \pm 20$ & 7.5 \\
438 & $1.8 \times 10^{-2}$ & $895 \pm 20$ & 10.5 \\
485 & $5.2 \times 10^{-2}$ & $1068 \pm 10$ & 19 \\
492 & $6.05 \times 10^{-2}$ & $1055 \pm 3$ & 18 \\
508 & $8.9 \times 10^{-2}$ & $1085 \pm 5$ & 20.5 \\
532 & $1.55 \times 10^{-1}$ & $1181 \pm 3$ & 31 \\
543 & $2.01 \times 10^{-1}$ & $1190 \pm 3$ & 33 \\
562 & $3.2 \times 10^{-1}$ & $1196 \pm 3$ & 34.5 \\
569 & $3.8 \times 10^{-1}$ & $1221 \pm 3$ & 38 \\
600 & $7.6 \times 10^{-1}$ & $1234 \pm 3$ & 46 \\
616 & 1.18 & $1235 \pm 4$ & 55 \\
645 & 1.95 & $1231 \pm 4$ & 57.5 \\
673 & 3.35 & $1205 \pm 5$ & 64.5 \\
711 & 6.6 & $1185 \pm 5$ & 68 \\
\hline
\end{tabular}

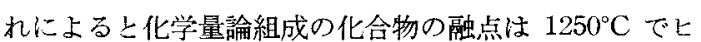
絜蒸気圧上して約 0.8 気圧が必要である. したがってヒ 化ガリウムの結晶をつくるには帯溶融法, 浮遊帯溶融 法, 引き上げ法のいずれの方法によるにせよ 0.8 気圧程 度の七素の蒸気压のふんい気中で操作せねばならないの で装置にも複雑な技術が要求される。

Richards $^{(5)}$ の考案による帯溶融装置は図 4 に示すよう にアランダムの炉心管の内面に沿ってカンタル線を巻い た反心炉上，その一端に，これと密接した補助電気炉を もらけた炉の構造をしている。これに化学量論組成にひ 
よう量したガリウムとヒ素をスーティングをほどこした 石英ボートに入れ，これを過剩の七素上ともに石英のア ンプルの中に真空に封じこむ.このアンプルの中の石英 ボートが炉の中心に位置するように反店炉の中にアンプ ルを置くようにする。そして龙态炉の温度を $800^{\circ} \mathrm{C}$ 亿調 節すると，耐火レンガで周囲をかこまれた部分泣 $1240^{\circ} \mathrm{C}$ 以上となり化学量論組成に近い上化ガリウムの溶融体を つくることがでさる。この際これと平衡する素の䓏気 压注補助電気炉の温度を $600^{\circ} \mathrm{C}$ に調節して 0.8 気压化 保つことができる。

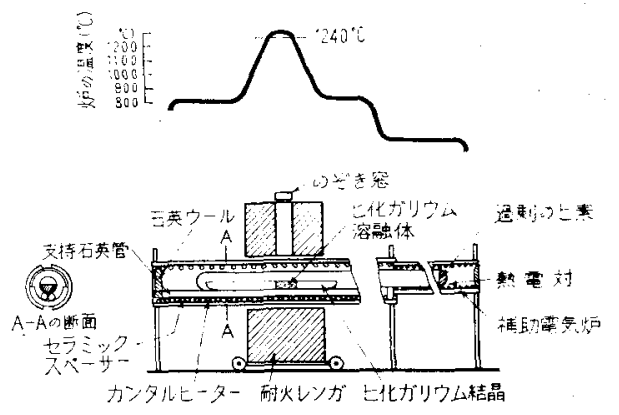

因 4 ヒ化ガリウムの製泣 (Richards)

このようにして保温用のレンガを移動させる上溶融带 も移動しヒ化ガりウムのインゴットをつくることができ る. 溶融帯の移動速度は $1.25 \sim 5 \mathrm{~cm} / \mathrm{hr}$ である。この 方法で単結晶をつくるときには溶融体とボートとの龙 応，ならびに溶融帯と固相との境界面の形に注意在払は なければならない，前者についてはインゴットが石英ボ 一トに固着し石英ボートを破損するおそ机がある。これ も酸化物があったり，ボートが污染しているときには特 にはげしい。これをさけるためには石英ボートにスーテ イングをしたあ上にアルゴンガス中で $1100^{\circ} \mathrm{C} て ゙ 2$ 時 間，加熱処理を行ないたものを用いる上よい，また後者 については固相一液相の境界面はインゴットの钱さ力问 に対して直角か，むしろ固相が液相の中に向ってトッ形 になるように加熱電力を調節しなければならない。この ように固相一液相の境界面の形を観察するために電気炉 の上部にスリットを設け，保温用の耐火レンガにはのぞ き空を設けてある。この装置では長さ $23 \mathrm{~cm}$ ，断面積 $1.5 \mathrm{~cm}^{2}$ で長さ方向はく111>の結晶軸之 $10^{\circ}$ 以内の傾 きをもった単結晶のインジットを造るこ上ができる。

不純物の点ではスーティングをほどこした石英ボート では結晶の中に炭素が溶けこみ，その溶解度が $10^{17} \mathrm{~cm}^{-3}$ 程度であるのでここれ以上の高純度の結晶をつくること は困難である。一般にヒ化㔯りウムの中の不純物は酸 素,シリコン，銅,テルル,マグネシウムなどで，酸素， シリコン，銅は石英より混入するのがおもな原因であ る.シリコンの影響を補償するには酸素をドープし $10^{7}$ $\Omega \mathrm{cm}$ 程度の高抵抗の結晶をつくるここができる゙,6).
つぎに引き上げ法による站結晶作成の装置の 1 つ例 として Weisberg 9) の考案した装置を図 5 に示す.この

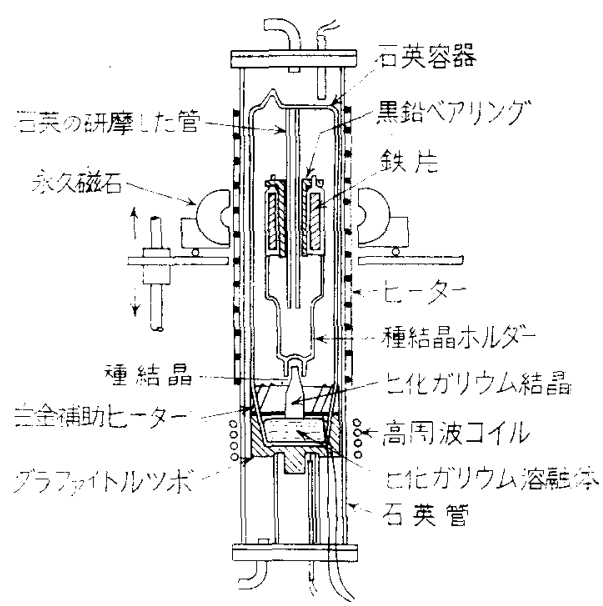

刚 5 ヒ化ガリウム引!き上げ装䈯 (Weisberg)

装置では上化ガリウムの溶融体之種結晶老保持するホル ダーを 1 つの石英容器の中に真空に封じ込み、これ音 $1 つ の$ 石英管の中に入れ，この石英管の底の部分にある グラファイトルッボを高㖇波加熱することによりヒ化が リウム在溶融する. 外側の不英管の内部には不活性が ス を流し，グラファイトルツボが酸化するのを防ぎ，一方 外側には電熱線を巻き $600^{\circ} \mathrm{C}$ に加熱し 石英容器内 $0 飞$ 素の蒸気圧が一定に保た机るようにする。種結晶のホル ダ一はその上端部で, 研摩した石英棒の周囲をグラファ イトのベアリングを介して，外部の永久磁石上内部の鉄 片の吸引力によってなめらかに同転しながら上下に運動 寸ることができる。

この場会, ヒ化ガリウムの溶融体の周围の石英容器の 側壁が蒸発物で不透明になり，作業の妨げとなるので， その部分に白金の補助ヒ一ターで加熱し蒸発物の凝集龺 防ぎ透明に保つようにしてある。また石英容器の内部に 純度の高いアルゴンガスを封入しておく上不透明になる ことを防止できるし，また七素の蒸気が溶融体えの急激 な出入のために溶融体の中におこる対流や进出とを抑制 することができる。この方法によってつくられた単結晶 インゴットは直径 $2 \mathrm{~cm}$, 長さ $12 \mathrm{~cm}$ 程度である.

このほかに，石英管のすり合わせで素の蒸気を封止 する方法 ${ }^{10)}$ や，溶融ガリウムで外界と七素蒸気をしお断 する方法"棉どが報告されている。

浮遊帯溶融法に上る成畏についても多くの方法があ る、Whelan ら ${ }^{12}$ はヒ化ガリウムのインゴットを石英管 の中に封じ込んで浮遊帯溶融法によって, 直径 $6 \mathrm{~mm}$, 琵さ $19 \mathrm{~cm}$ の単結晶をつくることができたと報告して いる、また Cunnel1 $1^{13}$ は真空に封し込むかわりに，石英 のすり合わせを利用した図6に示すような方法を若案し た。これによる上外側の石英管と精密にすり合わせた石 
烡の縥をピストンにし， そ竌にヒ化ガリウムのイ ンゴットを保持させる. 市引合わせの部分は直径 $15 \mathrm{~mm}$, 長さ $7 \mathrm{~cm}$ にわ たり, 間げきは $5 \mu$ 以下 と寻う精密なものであ る. 匕素の蒸気圧を一定 に偣つためには外部のグ ラファイトヒーターで加 歖ナる。この際にすり合 ら立の外部よりヒ素の蒸

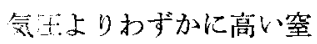
絮の王力を加え, 圧力の

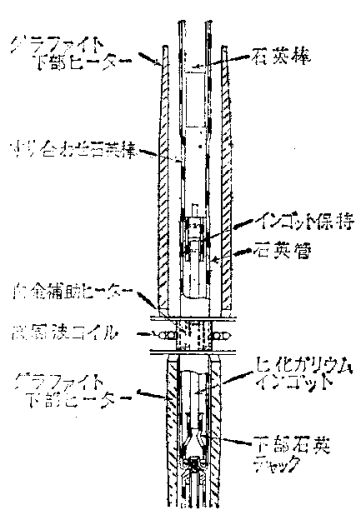

図 6 ヒ化がリウム浮遊带精製法 (Cunnell)
均衡を保つようにする。浮遊帯溶融をする部分は $4 \mathrm{Mc}$ の高周波の誘導加熱により溶融し, その周囲の壁が蒸発 物で不透明になるのを防止するために白金の補助ヒー夕 一が設けられている.この精密なすり合わせを用いると 七荸蒸気の漏えいは 1 時間に数ミリグラム以下に招さえ ることができる．この方法は真空に封じ込む方法より簡 巣な操作ですむので注目に值する方法であるがすり合わ せに流高級な技術が要求される。これらの装置でつくら 孔た結晶は抵抗率は $10^{-2} \sim 10^{6} \Omega \mathrm{cm}$ の単結晶であり， 浮遊帯精製の效果もかなり顕著であるが, 抵抗萃の高い もののなかには深いアクセプタ準位によるものもあっ て、必ずしも高純度のためではない。

\section{5 リン化ガリウム $(\mathrm{GaP})$}

溶融ガリウム中のリンの溶解度と平衡圧の関係はヒ化 ガリウムのように明確ではないが, 化学量論組成の溶融 体の平衡圧は20気圧より高いので結晶成長技術も困難 である。原理的には化ガリウムをつくるのと同様な方 法が用いられるが蒸気圧が高いために，爆発の危険性も 多く, 圧力容器の中で合成するのが安全であり, かつ多 量の処理が可能である。これは Frosch ら ${ }^{14)}$ の考案した 与法で図 7 に示すように, 長さ $75 \mathrm{~cm}$, 内径 $25 \mathrm{~cm}$, 肉 曆 $5 \mathrm{~mm}$ の不錆鋼の圧力容器の中にリンの蒸気圧を調 館与当ための電気炉を収め, その中心部に沿って反怘を

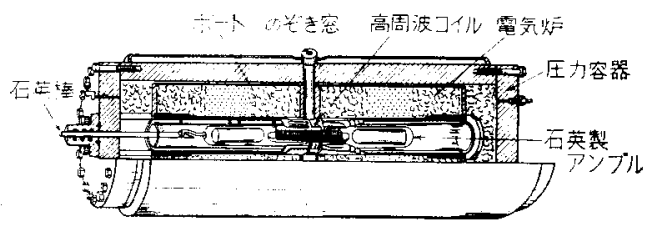

図 7 リン化ガリウムの製法 (Frash)

起こきせるための高周波加熱用の線輪をおく、ボートに 入れたガリウムと、リンを一つの石英のアンプルに真空 に施こみ，これを反応炉の中心部に㧍く、最初ガリウ 2、の人ったボートの一端を $900^{\circ} \mathrm{C}$ に高周波加熱し，この
部分のリンを蒸発させ，つぎにアンプル全体を加熱し， アンプル内のリンの蒸気圧を6〜35気压の範围で反応さ せて実験を行なった。この場合, 压力容器の内部に 10 気圧のアルゴンガスを圧入しアンプル内のリンの蒸気压 に拮抗させ爆発するのを防ぐ.リンの蒸気圧が一定に達 した後, アンプルの一端につけた石英棒でアンプルを $3 \mathrm{~cm} / \mathrm{hr}$ の速度で移動し，ガリウムとリンの反応を順次 行なわせる. 合成が終わった後は,この操作を繰り返え して帯溶融法により精製を行なうことができる。この装 置でリンの蒸気压を 20 気圧にして, 庈応温度を $1,450^{\circ} \mathrm{C}$ より $25^{\circ}$ おきに $1550^{\circ} \mathrm{C}$ までおのおのの温度で合成を行 なった結果, $1500^{\circ} \mathrm{C}$ 以下でっくった結晶は表面が荒く 多孔性であるのに反し， $1500^{\circ} \mathrm{C}$ 以上でつくったものは 平滑な表面をし透明度のよ、結晶がえられた。この結果 より化学量論組成をもったリン化ガリウムの融点は $1,500^{\circ} \mathrm{C}$ に近いものと思われる.この実験でグラフォイ トボートを用いて反応させた結晶は $p$ 型で，石英に久 一ティングをしたボートでは $n$ 型の結晶がつくられ， いずれも結晶粒塊の大きな多結晶である。不純物濃度は $p$ 型では $10^{16} \sim 10^{18} \mathrm{~cm}^{-3}, n$ 型では $10^{16} \sim 10^{19} \mathrm{~cm}^{-3}$ 程度 である。

またヒ化ガリウムと同じように引き上げ法, 带溶融法 によっても単結晶をつくることができるが，この場命に ルツボ，ボート材として用いられる炭素はリン化ガリウ ムに対して $10^{16} \sim 10^{17} \mathrm{~cm}^{-3}$ 程度の溶解度をもっており, これがアクセプターとして作用するので, 純度の高、結 晶をつくるには浮遊帯溶融法を利用するのが最適であ る.

浮遊帯溶融法について はFrosch ら“は図8に 示すように $6 \mathrm{~mm}^{2}$ の! ン化ガリウムのインゴッ トの両端を, 石英のアン プルの内面に緊密に接触 する石英管で支持し，ア ンプルの内部に過剰のリ ンをスれて, 真空に封止 する.このアンプルを一 様に一定温度に加熱して リンの蒸気圧を一定に保 ち,インゴットの一部を 高周波誘導で加熱溶融 し, 浮遊帯溶融を行なう.

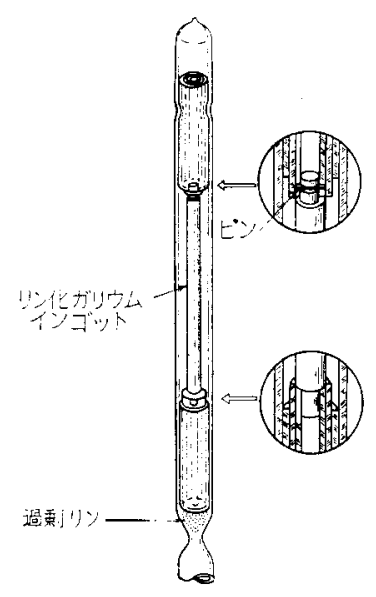

图 8 リン化ガリウムの浮遊带精 製法 (Frosh)
このときに使用した周波数は $120 \mathrm{Mc}$ と $12 \mathrm{Mc}$ とで実 験を行なった結果, $12 \mathrm{Mc} の$ 方が安定に溶融することが できた。虫た内径 $12 \mathrm{~mm}$ のアンプルを利用してリンの 蒸気圧 35 気玨に耐えて実験を行なうことができた。

実駼条件は, リンの蒸気圧 12〜20 気压で, 浮遊帯の 
移動速度 $2 \mathrm{~mm} / \mathrm{min}$ で透明な結晶をつくることができ た。

精製効果も比較的㪟著にあらわれ不紌物濃度も減少し $n$ 型の結晶で電子の易動度も $110 \mathrm{~cm}^{2} / \mathrm{Vsec}$ で現在では 最も高純度の結晶がえられている。

このように高い平衡圧を必要とする結晶の作成には複 雑な技術が伴うのでこれらの困難を避けるために T.S. M 法 (Travelling Solvent Method) によって Broder $ら^{15}$ はリン化ガリウムの比較的大きな結晶をつくること に成功した。

これは図 9 に示すよう にサファイヤ，石英また はアランダムの直径 1 $\mathrm{cm}$ 程度のアンプルの底 に単結晶をおき，その上 にガリウムをおく．さら にその上に原料となるリ ン化ガリウムの粉末とガ リウムの混合物，あるい は粉末を圧縮成型し焼成 した棒状の原料をおく。 この原料の占める体積は アンプルの全体積の75\%

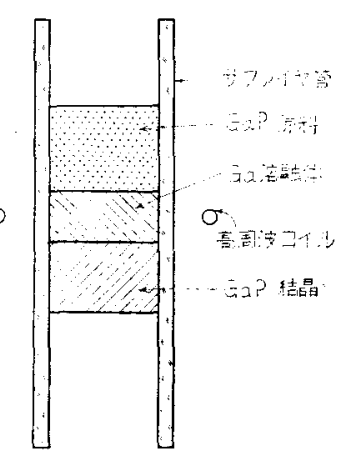

龱 9 リン化ガリウムり T.S.M 化よる製法 (Broder)
程度を占めるように充てんし，高周波加熱によってガリ ウムを $1000^{\circ} \mathrm{C} \sim 1100^{\circ} \mathrm{C}$ に加熱する. ガリウムの溶融体 の幅は $0.6 \sim 1.2 \mathrm{~cm}$ に調節する。この場合, 高温部よ りガリウムの中に溶け込んだリン化ガリウムは低温部に ある種結晶の上に析出結晶し単結晶が作成される。結晶 の成長につれて溶融带を $0.6 \mathrm{~cm} / 24 \mathrm{hr}$ 程度の速度で移 動し直径 $1 \mathrm{~cm}$, 長さ $2 \mathrm{~cm}$ 程度の結晶をつくることが できた。

\section{6 ヒ化インジウム(InAs)}

Boomgard $^{5}$ によるインジウム中のヒ素の溶解度と平 衡圧の関係は表 2 に示すように化学量論組成のヒ化イン ジウムの溶融体のヒ素の平衡压は約 0.85 気圧であるの で比較的つくりやす、結晶である. Cronin ら は渴 10 表 2 In-As 系の As の蒸父压-温度-As の含有量の関係

\begin{tabular}{|c|c|c|c|}
\hline 渴。席 & 七素の蒸気王 & $\begin{array}{l}\text { 化会物。融点 } \\
\left({ }^{\circ} \mathrm{C}\right)\end{array}$ & $\begin{array}{c}\text { 溶䖪体中の上素\%) } \\
\text { (atom } \% \text { ) 有量 }\end{array}$ \\
\hline 438 & $1.53 \times 10^{-2}$ & $790 \pm 5$ & 20.5 \\
\hline 473 & $4.10 \times 10^{-2}$ & $875 \div 5$ & 32 \\
\hline 520 & $1.18 \times 10^{-1}$ & $928 \pm 3$ & 44 \\
\hline 532 & $1.71 \times 10^{-1}$ & $938 \pm 3$ & 49 \\
\hline 553 & $2.45 \times 10^{-1}$ & $936 \pm 4$ & 48 \\
\hline 576 & $4.8 \times 10^{-1}$ & $942 \div 3$ & 51.5 \\
\hline 600 & $8.3 \times 10^{-1}$ & $939 \pm 3$ & 57.5 \\
\hline 619 & 1.02 & $931 \pm 3$ & 60 \\
\hline 661 & 2.50 & $896 \pm 3$ & 69 \\
\hline 662 & 4.8 & $868 \pm 4$ & 75.5 \\
\hline 720 & 7.7 & $825 \pm 4$ & 81.5 \\
\hline 735 & 9.7 & $781 \pm 3$ & 86 \\
\hline
\end{tabular}

に示すような比較的小規 模の引き上げ装置で単結 晶を作成した。

これは熱電対をそう入 した台の上に内径 7.5 $\mathrm{cm}$, 長さ $25 \mathrm{~cm}$ の石英 管を密着させ，その上端 にはヒ素が凝縮しないよ うに加熱できる等化ホウ 素製のふたをのせ，その 中心部にあるグラファイ トのベアリングを通して

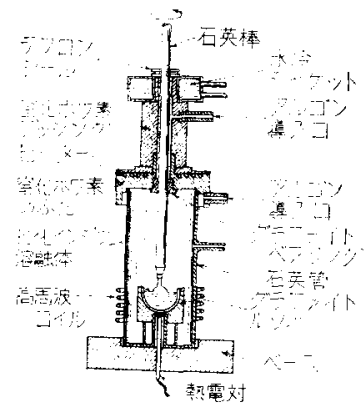

図 10 ヒ化インジウムの引ま 竝置 (Crohin)
種結晶を保持する石英の棒を貫通し，その上にさらに空 化ホウ素で造ったブッシングをもうけ，その端でテフロ ンシールで石英棒を固定し，棒とブッシングの間げきに アルゴンガスを入れて反応空よりヒ素の蒸気の流失を汸 止する. 最初にインジウムをルツボの中に入れ，こ机に 対灾する化学量䜽組成より 7〜10\%過剩の七素を反応空 の底におく，反応室の側管よりアルゴンガスを導入し反 応室の内部をガスで洗浄した後真空にして側管を封止す る.グラファイトルツボを高周波加熱するとその放身熱 でヒ素が昇華しインジウムと反応し，ヒ化インジウムの 溶融体をつくる，反忘が完了すれば温度を一定に保ち同 転数 $20 \mathrm{rpm}$,引き上げ速度 $3 \sim 4 \mathrm{~cm} / \mathrm{hr}$ で単結晶が引 き上げられる。

99.999\%の純度のインジウムとヒ素より作成した単結 晶は $n$ 型で, 室温では不純物濃度 $1.72 \times 10^{16} \mathrm{~cm}^{-3}$, 泜 抗率 $1.3 \times 10^{-2} \Omega \mathrm{cm}$, 電子の易動度は $300^{\circ} \mathrm{K}$ で 27400 $\mathrm{cm}^{2} / \mathrm{Vsec} 77^{\circ} \mathrm{K}$ では $61200 \mathrm{~cm}^{2} / \mathrm{Vsec}$ である.

\section{7 リン化インジゥム (InP)}

インジウム中のリンの溶解度と平衡圧の関係はBoom. gard によると表 3 に示すように化学量論組成の平衡)

表 3 In-P 系のPの蒸気圧-温度-P の含有量の関係

\begin{tabular}{|c|c|c|c|}
\hline$\stackrel{\left.{ }^{\circ}{ }^{\circ} \mathrm{C}\right)}{ }$ & $\begin{array}{l}\text { リンの蒸気压 } \\
\text { (atm) }\end{array}$ & $\begin{array}{l}\text { 化合物の融点 } \\
\left({ }^{\circ} \mathrm{C}\right)\end{array}$ & $\begin{array}{c}\text { 溶融体中のリンの合有是 } \\
(\text { atom } \%)\end{array}$ \\
\hline 338 & 0.10 & 860 & 15.6 \\
\hline 375 & 0.32 & 940 & 21.0 \\
\hline 400 & 0.60 & 962 & 25.3 \\
\hline 420 & 1.1 & 983 & 34.0 \\
\hline 450 & 2.3 & 1013 & 36.5 \\
\hline 480 & 4.8 & 1023 & - \\
\hline 515 & 10.5 & 1030 & 45.9 \\
\hline 547 & 20 & 1043 & 43.6 \\
\hline 585 & 40 & 1057 & 47.7 \\
\hline
\end{tabular}

は 60 気圧近いものと思われる。したがって製法も还難 であるが，Weisberg ${ }^{17}$ は図11 (A) に示すように内径 $1 \mathrm{~cm}$, 長さ $15 \sim 20 \mathrm{~cm}$, 肉厚 $3 \mathrm{~mm}$ の石英管の中にイン ジウムとリンを封入してアンプルをつくり，これを2つ の部分 $\mathrm{A}, \mathrm{B}$ に分けられた炉の中におく．炉の温度分有 は図 11 (B) に示すように低温部は $530^{\circ} \sim 550^{\circ} \mathrm{C}$ 保与 


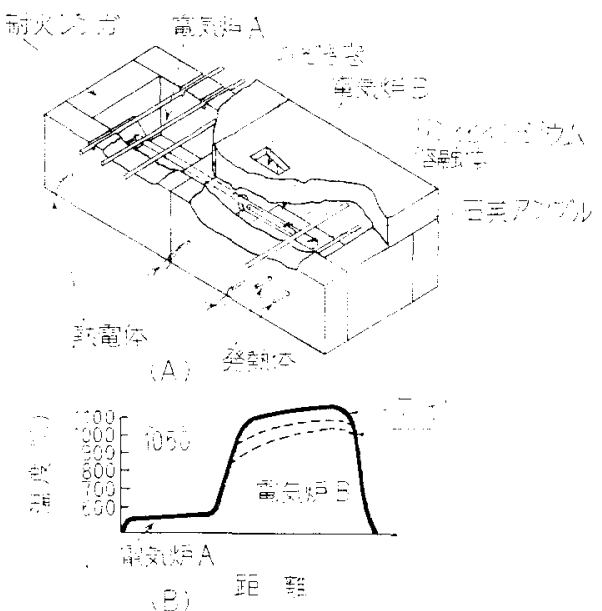

図 11 リン化インジウムの製法 (Weisberg)

リンの蒸気圧を $15 \sim 20$ 気王にし，高温部は $1150^{\circ} \mathrm{C} に$ して反応を起こさせリン化インジウムの溶融体をつく る.その後図 11 (B) の点線で示した温度分布になるよ うに温度を下げると溶融体の一端より約 $1 \mathrm{~cm} / \mathrm{hr} の$ 速度 で結晶化が法じまり，単結晶のインゴットをつくること ができる。この方法法可動部分がなく比較的簡単に製作 できる。

また Harman ら ${ }^{17)}$ は封止した石英管の中で引き上げ 法によって単結晶をつくることに成功しこれらの結晶 は $n$ 型であり，不純物濃度は $1 \times 10^{17} \mathrm{~cm}^{-3}$, 電子の移動 度は $300^{\circ} \mathrm{K}$ で $4,000 \mathrm{~cm}^{2} / \mathrm{Vsec}$ である。

上に述べてきた方法は一般に大きな単結晶インゴット をつくる方法であるが，蒸気圧の高い元素を成分にもつ 化合物半尊体ではつくるのに非常に複雑な装置が必要に なり，また融点の高いものが多く，容器および装置の一 部より不純物が混入するおそれがあるので，高純度の結 晶安つくることは困難である。これらの困難を克服する ために，比較的低、温度で反応させる気相成長法があ Ђ.

\section{3 エピタキシャル成長法}

化合物半導体のおのおのの成分を気相で反忘さ せ，これを単結晶基板の上に成長させるこピタキ シャル成長法は, 最近半導体工業においてきわめ て重要な技術として注目をあびている。これ注 板の上の必要な部分にのみ，結晶を成長させる部 分的選択成長ができることと，不純物の濃度を目 的に応じた分布に導入することができる利用をも っている.

\section{1 封 管 法}

これは闵 12 に示すように単結晶の基板上，原 料のヒ化ガリウム結晶を石英のアンプルに真空に 封じこむ。このときに原料のヒ化ガりウムが気相
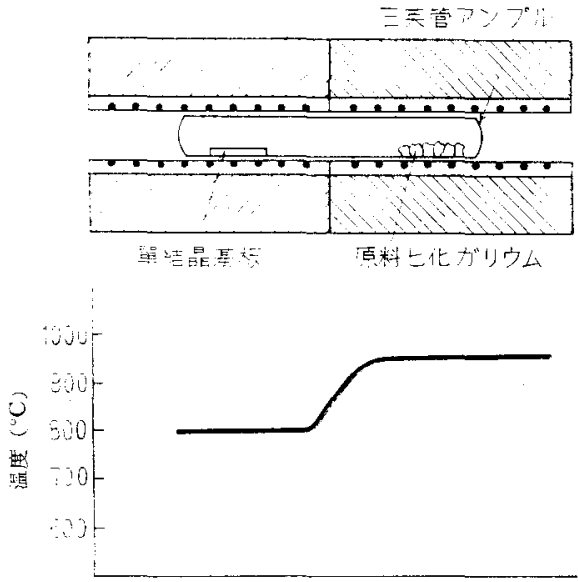

図 12 ヒ化ガリウムのエピタキシャル成長法（封管法）

を経由して基板の上に移動するためのキャリヤーガスと してヨウ素あるいは塩化水素をアンプルの中に封じこん でおく、このアンプルを図に示ような温度傾斜をもった 電気炉の中におくと原料化ガリウムは移動して基板の 上に新しい単結晶層が成長する．これは化ガリウムの 封管法によるエピタキシャル成長法であるが，リン化が リウムなどでも同じような方法を適用するこ上ができ 万。

\section{2 開 管 法}

開管法では封管法のように原料ヒ化ガリウム結晶上其 板結晶をアンプルに封しこまずに，温度傾斜をもった反 応炉の中の高温部に原料結晶をおき，低温部には基板单 結晶をおき，その中を三塩化ガリウムと水素の混合気 体，または，塩化水素と水素の混合気体をキャリヤーガ スとして流し単結晶層を成長させる。

また原料ヒ化ガリウムを用いずに気相反応でヒ化ガり ウムを合成し，これを基板の上に成長させる方法があ b.

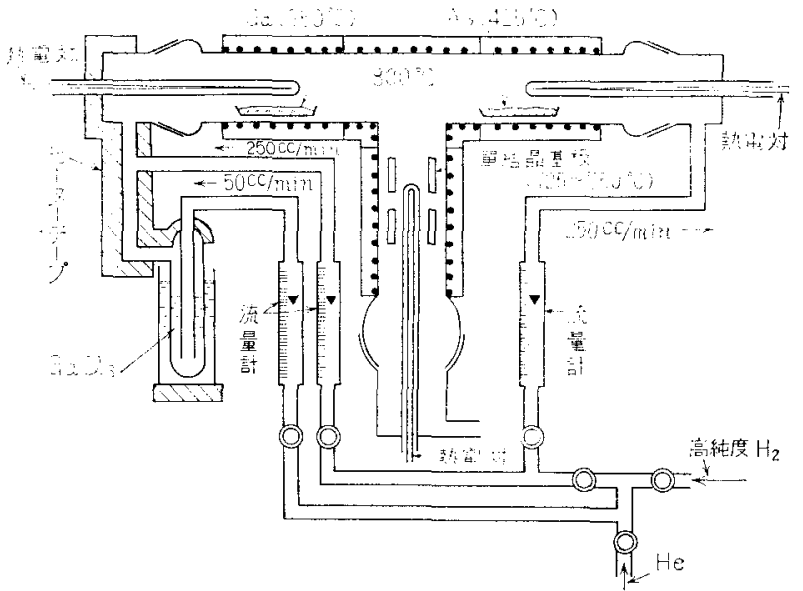

㧄 13 ヒ化ガリウムいエピタキシャル泣（開管法） 


$$
\begin{array}{ll}
\text { これには } & \mathrm{GaCl}_{3}+\mathrm{AsCl}_{3}+\mathrm{H}_{2} \\
& \mathrm{GaCl}_{3}+\mathrm{As}_{4}+\mathrm{H}_{2} \\
& \mathrm{Ga}+\mathrm{As}_{4}+\mathrm{HCl}+\mathrm{H}_{2} \\
& \mathrm{Ga}+\mathrm{GaCl}_{3}+\mathrm{As}_{4}+\mathrm{H}_{2}
\end{array}
$$

などの反店系が利用されている。图 13 は三湓化ガリウ ム乞ヒ素，ないしはガリウムと七素を原料として友応管 外でヒ化ガリウムの合成を行ない，これを単結晶基板の 上に析出させて成長させる装置である ${ }^{18)}$.

一般にヒ化ガリウムでは成長温度は気相の化学組成に 上っても異なるが大体 $650^{\circ} \mathrm{C} \sim 900^{\circ} \mathrm{C}$ の範囲であり，成

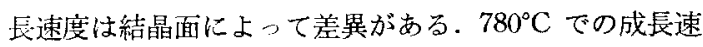
度は（1 $111 ）$ 面上では毎分 10 分の数ミクロンであるが (11i）面上ではとの 10 分の 1 程度である ${ }^{19}$.

これらの方法は一般に成長温度が低いので容器よりの 否絽物のとりこみが少なく，また反応にあゔかる成分も 高級度のものがえられるので純度の高い結晶を作ること ができるのは大きな利点である。

\section{文}

\section{献}

i) K.F. Hulme, J.Electronics 6, 397 (1959).

2) W.P. Allred, W.L. Mefferd, R.K. Willardson, J. Electrochem. Soc 107, 117 (1960).
3 D.F. Edward, G.S. Hayne, J. Opt. Soc. Am. 49, 414 (1959).

4) W.P. Allred, R.T. Bate, J. Electrochem. Soc. 108, 258 (1961).

5) J. Van den, Boomgard, K.Schol, Philips. Res. Repts. 12. 127 (1957).

6) J.L. Richards, J. App. Phys. 11, 600 (1960).

7) N.G. Ainslie, S.E. Blum, I.F. Woods, J. App. Phys. 33, 2391 (1962).

8) J.F. Woods, N.G. Ainslie, J. App. Phys. 34, 1469 (1963).

9) L.R. Weissberg, F.D. Rosi, P. Herkart, AIME Conference Bosto (1959).

10) P.L. Moody, C. Kolm, Rev. Sci. Inst. 29, 1144 (1958).

11) J.L. Richards, J. Sci. Inst. 34, 289 (1957).

12) J.M. Whelan, G.H. Wheatley, J. Phys. Chem. Solid 6. 169 (1958).

13) C. Hilsum, A.G. Rose-Innes (Ed), Semiconducting III $-V$ Compounds (1961), Pergamon Press. Oxford.

14) C.J. Frosh, L. Derik, J. Electrochem. Soc. 108, 251 (1961).

15) J.D. Broder, G.A. Wolff, J. Electrochem. Soc. 110, 1150 (1963).

16) G.R. Cronin, J.E. Morton, O. Wilson, J. Electrochem. Soc. 110, 582 (1963).

17) L.R. Weisberg, F.D. Rosi, P.G. Herkart, Properties of Elementary and Compound Semiconducters vol 5 (1959), Interscience New. York.

18) N. Goldsmith, W. Oshinsky, RCA Rev. 24, 546 (1963).

19) R.E. Bwing, P.E. Greene, J. Electrochem. Soc. 111, 1266 (1964). 